\title{
CORRIGENDUM
}

\section{The Effect of Specific Glycosidases on Ricinus communis Agglutinin Binding to Cell Surfaces of Two Tumor Sublines}

\section{A Comparative Flow-Cytometric Study}

B. BOHN, * R. BROSSMER, G. KEILICH, H. GALJAARD, $\dagger$ AND F. VERHEUEN†

Institut für Biochemie II (Med. Fak.) der Universität Heidelberg, Im Neuenheimer Feld 328, D-6900 Heidelberg, Germany and tDept of Cell Biology and Genetics, Medical Faculty, Erasmus University Rotterdam, The Netherlands

In this article, which appeared in Cell Biophysics 6, 171 (1984), the numerals on the ordinate of Fig. 1 on p. 178 should read 4.0, 8.0, and 12.0 instead of $2.0,4.0$, and 6.0 . 